\title{
COMMUNISM IN CENTRAL AMERICA AND THE CARIBBEAN
}

Robert Wesson - Editor

Central America and the Caribbean are deeply troubled areas and their peoples ready recruits for radical movements. These concerns form the background for the nine essays in this volume. Two focus on the regional influence of Cuba and the Soviet Union, the others are individual surveys of particular nations.

Xiv+177pp paper $\mathbf{f 7 . 7 0} 1982$ - 0817976124

\section{CONSTRAINT OF EMPIRE: The United States and Caribbean Interventions} Whitney T. Perkins

Constraint of Empire traces the policies and actions of the US towards Cuba, Nicaragua, the Dominican Republic and Haiti. The US intruded into these nations trying to implant political practices compatible with its own interests. This volume illustrates the goals, process and limitations of American imperialism.

xv+282pp case $€ 21.751982$ - 0903450526

PANAMA Eleanor Deselms Langstaff World Bibliographical Series 14

Panama, even when a province of Colombia, was known as an important even exotic crossroads, which had seen the passage of conquistadores, explorers, pirates, gold hunters and canal builders with grandiose plans.

c200pp case c£20.00 1982 - 0903450267

\section{THE LATIN AMERICAN POLITICAL DICTIONARY Ernest E. Rossi and} Jack C. Plano Clio Dictionaries in Political Science 1

"This well-organised, easy-to-read reference work is indispensable for anyone interested in Latin America: The authors provide precise and clear definitions of concepts vital to the understanding of Latin American history and politics. They also include accurate descriptions of the events, people and institutions which most strongly influenced the area's social and political history." Francis $A$. Dutra xli+261pp case E13.95 1981 - 0874363241

\section{BETWEEN BLACK AND WHITE: Race, Politics and the Free Coloureds in Jamaica, 1792-1865 Gad J. Heuman}

Free Coloureds occupied an anomalous position in Jamaican society. They were denied the rights enjoyed by whites, and they sought to distance themselves from slaves; the result was a social and economic system where colour denoted class. $x x+282 p p$ case $£ 20.001981$ - $090345050 x$

GUATEMALA Woodman B. Franklin World Bibliographical Series 9

This is the only up-to-date critically annotated bibliography on Guatemala, and it is an essential reference source for the region.

xiv+109pp case $£ 15.001981$ - 0903450240

\section{A GUIDE TO THE HISTORY OF BRAZIL, 1500-1822: The Literature.} in English Francis A. Dutra

"This well-written guide, in the form of an annotated bibliography, is a very useful contribution to Brazilian and Latin American studies... Highly recommended." Choice

"It is the first complete bibliography to be published in English in this area and the first major review of the history of colonial Brazil in English since the 19th century... Carefully organised to help readers find what they need easily and quickly." In View xxxviii+625pp case $£ 25.951980$ - 0874362636

BELIZE Ralph Lee Woodward jr. World Bibliographical Series 21

"A finely produced and up-to-date tool for the study of an area of increasing interest today." British Bulletin of Publications on Latin America, The Caribbean, etc. xxii+229pp case $£ 21.001980 .0903450410$ 


\section{INSTITUTE OF LATIN AMERICAN STUDIES}

\section{University of London}

WORKING PAPERS

1. Oil and and Politics in Ecuador, 1972-1976 by George Philip (1978), 31 pp.

2. Industrial Investment in an 'Export' Economy: the Brazilian Experience before 1914 by Flavio Rabelo Versiani (1979), 40 pp.

3. Peruvian Labour and the Military Government since 1968 by Alan Angell (1980), $51 \mathrm{pp}$.

4. Labour in Chile under the Junta, 1973-1979 by Gonzalo Falabella (1981), 61 pp.

5. W. H. Hudson: the Colonial's Revenge. A Reading of his Fiction and his Relationship with Charles Darwin by Jason Wilson (1981), 26 pp.

6. Development Policymaking in Mexico: the Sistema Alimentario Mexicano (SAM) by Michael Redclift (1981), 17 pp.

7. Brazilian Private Industrial Enterprise, 1950-1980 by Susan M. Cunningham (1982), $51 \mathrm{pp}$.

8. Bolivia 1980-1981: The Political System in Crisis by James Dunkerley (1982), 48 pp.

Price per copy, including postage: United Kingdom and Europe $£ 1.25$ Overseas (airmail) US $\$ 5.00$

Latin American Studies in Great Britain: An Autobiographical Fragment by

R. A. Humphreys (2nd ed. 1982), 54 pp.

United Kingdom and Europe $£ 2.25$

Overseas (airmail) US $\$ 8.00$

Intercontinental Migration to Latin America: A Select Bibliography compiled by Juan Bailey and Freya Headlam (1980), $60 \mathrm{pp}$.

United Kingdom and Europe $£ 2.25$

Overseas (airmail) US $\$ 8.00$

31 Tavistock Square, London WC1H 9HA 


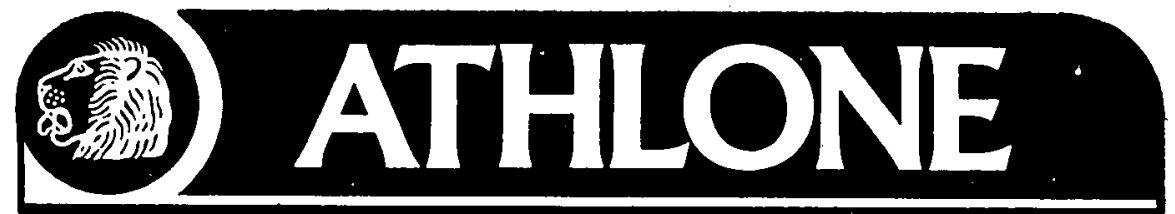

INSTITUTE OF LATIN AMERICAN STUDIES MONOGRAPHS University of London

\section{LATIN AMERICA AND THE SECOND WORLD WAR R. A. HUMPHREYS}

An authoritative, two-volume study of the involvement of the Latin American states in the Second World War. Volume One was published in 1981.

'This work will be essential for students of international history for many years.' British Book News

10. Volume One: $1939-1942 £ 16.00$

11. Volume Two: $1942-1945 £ 18.00$ September 1982

\section{Also available}

3. Commercial Relations between British Overseas Territories and South America 1806-1914 T. W. KEEBLE

4. British Nitrates and Chilean Politics. 1886-96: Balmaceda and North HAROLD BLAKEMORE

5. Directory of Libraries and Special Collections on Latin America and the. West Indies BERNARD NAYLOR, LAURENCE HALLEWELL and COLINSTEELE

6. Mexico State Papers 1744-1843: A Descriptive Catalogue of the G. R. G. Conway Collection in the Institute of Historical Research, University of London MICHAEL P. COSTELOE

7. Farmers in Revolt: The Revolutions of 1893 in the Province of Sante Fe, Argentina EZEQUIEL GALLO

8. Agrarian Reform and Peasant Organisation on the Ecuadorian Coast M. R. REDCLIFT

9. The Rise and Fall of the Peruvian Military Radicals 1968-1976 G. D. E. PHILIP

90-91 Great Russell Street, London WC1B 3PY

Distributed by J. M. Dent \& Sons (Distribution) Etd; Dunhams Lane, Letchworth, Herts, England 


\section{Peasant Cooperatives and Political Change in Peru}

\section{CYNTHIA MC CLINTOCK}

Sharing with other radical government leaders-such as Castro, Nyerere, Mao, and Allende-the common goal of developing a new political consciousness in their countries, General Juan Velasco Alvarado claimed to be leading Peru toward a "fully participatory social democracy" from 1968 to 1975 . To determine the extent to which this was true or even feasible, Cynthia McClintock examines Peru's experience with self-management and its effect on the political culture of the country's peasants.

Illus. Cloth, $£ 19.40$. Paper, $£ 4.95$

\section{Princeton University Press 15a Epsom Rd.} Guildford, Surrey GU1 3.JT Telephone (0483) 68364 


\section{Oil and Politics in Latin America}

Nationalist Movements and State Companies GEORGE PHILIP

This book studies the transformation of the Latin American oil system from one in which the international oil companies dominated to one in which the main state oil companies are pre-eminent. It also provides a comprehensive account of how some of the more important state companies have operated.

$£ 37.50$ net

Cambridge Latin American Studies 40

\section{Demographic Collapse}

Indian Peru, 1520-1620

NOBLE DAVID COOK

While there have been many estimates of the size of the Indian population of the Americas at the time of the first contact with Europeans, this book focusing on Peru - provides a thorough examination of the question.

'... a major contribution to early colonial history in Peru, ... will not soon be superseded.'

British Bulletin of Publications on Latin America

Cambridge Latin American Studies 41

$£ 22.50$ net

\section{Revolution from without}

Yucatán, Mexico, and the United States, 1880-1924

\section{GILBERT M. JOSEPH}

While agreeing that Yucatán's experience of the Mexican Revolution was in many ways exceptional, Professor Joseph also shows that the Yucatecan case throws light on central economic, social and political problems.

$£ 29.50$ net

Cambridge Latin American Studies 42

\section{White Servitude in Colonial America}

\section{DAVID W. GALENSON}

White servitude was one of the major institutions in early colonial British America. This study of the system of indentured servitude subjects the origins of this labour force to rigorous analysis and provides a quantitative description of the demographic, social and economic characteristics of over 20,000 indentured immigrants.

$£ 22.50$ net

\section{CAMBRIDGE UNIVERSITY PRESS}




\section{The Journal of American Studies Editor \\ Howard Temperley, \\ Professor of American Studies, University of East Anglia}

Sponsored by the British Association for American Studies

The Journal of American Studies publishes work by scholars of various nationalities on American literature, history, institutions, politics, economics, geography and related subjects. Articles which cross the conventional borders between academic disciplines are particularly welcome, as are comparative studies of American and other cultures. It also publishes review essays, book reviews and, biennially, a list of doctoral theses on American topics in progress and completed at British universities.

\section{Contents of Volume 16 Part 2 August 1982}

David Reynolds Whitehall, Washington and the Promotion of American Studies in Britain during World War Two

William E. Leverette, Jr., and David E. Shi Herbert Agar and Free America: A Jefferson Alternative to the New Deal

Michael Simpson Meliorist versus Insurgent Planners and the Problems of New York, 1921-1941

Lawrence Schwartz Malcolm Cowley's Path to William Faulkner Review Essay

Reviews

Volume 16: April, August and December 1982

$£ 24.00 / \$ 65.00$ per year Single parts: $£ 9.00 / \$ 25.50$

For further information please contact Journals Publicity at the address below.

\section{CAMBRIDGE \\ UNIVERSITY PRESS}

The Edinburgh Building. Shattesbury Road. Cambridge CB2 2RU. England 


\section{NEW BOOKS from Allen \& Unwin}

\section{Underdevelopment and Development in Brazil}

Volume I: Economic Structure and Change, 1822-1947

Volume II: Reassessing the

Obstacles to Economic

Development

Nathanial H. Leff; Columbia University

This major new work sets out to answer some fundamental questions in Brazil's economic history and in the analysis of long-term economic development.

Professor Leff's economic analysis of the 1822-1947 history of Brazil is a major contribution. It advances the knowledge that will serve not only economists but also historians.'

Professor T.W. Schultz

Available

Vol. I 272pp

0043303242 Hardback $£ 18.50$

Vol. II $160 \mathrm{pp}$

0043303250 Hardback $£ 12.50$

\section{The Theory and}

\section{Experience of Economic Development}

\section{Essays in Honour of Sir}

W. Arthur Lewis

Edited by Mark Gersovitz, Carlos F. Diaz-Alejandro, Gustav Ranis and Mark R. Rosenzweig

An international group of distinguished scholars provide. new perspectives on many of the most important theoretical and policy questions in economic development. These original essays address a varied set of specific issues reflecting Professor Lewis' research interests.

September $1982416 \mathrm{pp}$ 0043303234 Hardback $£ 22.50$
The Newly

Industrialising

Countries:

Trade and Adjustment

Louis Turner, Royal Institute ofInternational Affairs, London, and Neil McMullen, National

Planning Association, Washington $D C$.

A team of international political economists assesses why the NICs have been successful or otherwise in the major industrial sectors, and also analyses the problems of industrial adjustment of both those newer and older economies.
Available
$320 \mathrm{pp}$
$0043820360 \quad$ Hardback $£ 18.00$
The Royal Institute of International Affairs.

\section{Nuclear Power in the Developing World}

\section{Daniel Poneman,} Harvard University

This book explores the increasingly urgent issue of nuclear power policies in developing countries

November $1982 \cdot 272 \mathrm{pp}$

0043381006 Hardback $£ 14.95$.

\section{Rich and Poor Countries}

Third Edition

Hans Singer, Institute of

Development Studies,

University of Sussex, and Javed

Ansari, City University

\section{Available 272pp}

$0043303218 \quad$ Paperback $£ 5.95$

Studies in Economics: No. 12.

Prices are correct at time of going to press.

For further details write to:

Academic Sales Department,

George Allen and Unwin (Publishers) Litd., PO Box 18, Park Lane,

Hemel Hempstead,

Herts HP2 4TE. England. 


\section{A Social history of Black Slaves and Freedmen in Portugal, 1441-1555}

\section{A. C. DE C.M. SAUNDERS}

An unusually detailed study, based on extensive archival research. The author describes the institutional arrangements, labour, legal status, religious and social life of the slaves and freedmen, and demonstrates the effects of the growing black population upon Portuguese law, society, economy, and racial attitudes. $\$ 27.50$ net

Cambridge Iberian and Latin American Studies

\section{The Fall of Natural Man}

The American Indian and the Origins of Comparative Ethnology ANTHONY PAGDEN

The first serious study of the pre-Enlightenment methods by which Europeans attempted to describe and classify the American Indian and his society. It examines three groups of Spanish writers: Francisco de Vitoria and his followers, Bartolomé de las Casas, and José de Acosta.

E24.00 net

Cambridge Iberian and Latin American Studies

\section{CAMBRIDGE UNIVERSITY PRESS}




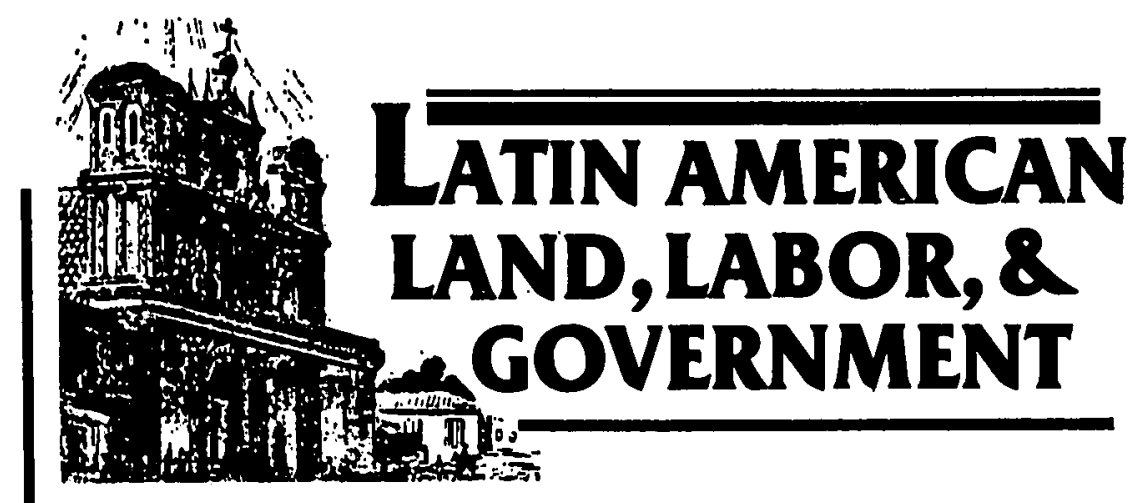

\section{GOVERNMENT AND SOCIETY IN CENTRAL AMERICA, 1680-1840}

Miles $L$. Wortman. The first intensive examination of the evolution of Central America from a baroque period through the age of enlightenment to independence and caudillismo. A KIng's Crown Paperback 384 pp., $\$ 15.00$

\section{WE EAT THE MINES AND THE MINES EAT US}

\section{DEPENDENCY AND EXPLOITATION IN BOLIVIAN TIN MINES}

June Nash. "For a combination of careful scholarship, broad perception . . ., and a sense of 'having been there,' serious students at any level will appreciate this fine ethnography." Sociology: Reviews of New Books. A King's Crown Paperback, 363 pp., $\$ 13.00$

\section{THE NITRATE INDUSTRY AND CHILE'S CRUCIAL TRANSITION: 1870-1891}

Thomas F. O'Brien. Probes the relationship between Chile and that country's important nitrate industry. Shows how foreign intervention in a prosperous national industry resulted in local impoverishment, eventual collapse of government stability, and the culmination of the Chilean Civil War. New York Unlversily Press 232 pp., $\$ 30.00$

\section{EXCAVATIONS AT HUACALOMA IN THE NORTH HIGHLANDS OF PERU, 1979}

\section{REPORT NO. 2 OF THE JAPANESE SCIENTIFIC EXPEDITION TO NUCLEAR AMERICA}

Kazuo Terada, editor. Covers chronological, stratigraphical, and comparative studies of Cajamacan culture. 8" $\times 111_{2}^{\prime \prime}$ with 140 plates. University of Tokyo Press 300 pp., $\$ 79.50$

\section{THE WARM VALLYY PEOPLE}

\section{DUALITY AND LAND REFORM AMONG THE QUECHUA INDIANS OF HIGHLAND PERU}

Herald 0. Skar. Examines the Peruvian land reform which has expropriated 25 million acres of land, replacing the former hispanic oligarchy with the Quechua Indians as the new owners of the land. Universitetsforlaget $243 \mathrm{pp} ., \$ 26.00$

Send lor our frese History catalog.

Send check or money order to Dept. JN at the address below, including $\$ 2.00$ per book order for poștage and handling. 


\section{JOURNAL OF LATIN AMERICAN STUDIES}

VOLUME 141982

Editors:

HAROLD BLAKEMORE

ALAN ANGELL

Editorial Board:

D. A. BRADING

S. D. W. COLLIER

P. FLYNN

R. A. HUMPHREYS

J. LYNCH

D. C. M. PLATT

B. ROBERTS

CLIFFORD T. SMITH

MRS R. THORP

Part I pages $1-252$

Part $2 \quad 253-498$

CAMBRIDGE UNIVERSITY PRESS

CAMBRIDGE

LONDON NEW YORK NEW ROCHELLE

MELBOURNE SYDNEY 
Published by the Press Syndicate of the University of Cambridge The Pitt Building, Trumpington Street, Cambridge, CB2 IRP 32 East 57 th Street, New York, N.Y. 10022, U.S.A.

(C) Cambridge University Press 1982

Printed in Great Britain by New Western Printing Ltd, Bristol 


\section{Articles}

ALBERT, Bill: Sugar and Anglo-Peruvian Trade Negotiations in the r93os

BLACKWELDER, Julia Kirk and JOHNSON, Lyman L.: Changing Criminal Patterns in Buenos Aires, 1890 to 1914

DEAS, Malcolm: The Fiscal Problems of Nineteenth-Century Colombia

FIFER, J. Valerie: The Search for a Series of Small Successes: Frontiers of Settlement in Eastern Bolivia

GOOTENBERG, Paul: The Social Origins of Protectionism and Free Trade in Ninteenth-Century Lima

HORNA, Hernán: Modernization and Entrepreneurship in NineteenthCentury Columbia

LITTLE, Walter: A Note on Political Incorporation: The Argentine Plan Político of 1955

MIDDLETON, Alan: Division and Cohesion in the Working Class: Artisans and Wage Labourers in Ecuador

MILLER, Rory: The Coastal Elite and Peruvian Politics

MORLEY, Morris H.: The U.S. Imperial State in Cuba, I952-1958: Policymaking and Capitalist Interests

NEWSON, Linda: The Depopulation of Nicaragua in the Sixteenth Century

ORTEGA, Luis: The First Four Decades of the Chilean Coal Mining Industry

PEREZ, Lisandro: Iron Mining and Socio-Demographic Change in Eastern Cuba, 1 884-1940

PORTOCARRERO M., Felipe: The Peruvian Public Investment Programme, $1968-78$

RIDINGS, Eugene W.: Business, Nationality and Dependency in Late Ninteenth Century Brazil

\section{Review Articles}

LUNDAHL, Mats: Haitian Underdevelopment in a Historical Perspective 


\section{Reviews}

Aguiar, Neuma: The Structure of Brazilian Development, by J. R. Heath

Anderson, Arthur J. O. and Dibele, Charles E. (eds.): Florentine Codex, Part I: Introductions and Indices, by Warwick Bray

Anna, Timothy E.: The Fall of the Royal Government in Peru, by John Lynch

Arbingast, Stanley A. et al: Atlas of Central America, by David. J. Fox

Avaria, Luis Valencia: Bernardo O'Higgins. El buen genio de América, by Simon Collier

Balmana, Altiva Pilatti: Santa Felicidade. Uma paróquia Venêta no Brazil, by R. F. Colson

Baloyra, Enrique A. and Martz, John D.: Political Attitudes in Venezuela: Societal Cleavages and Political Opinion, by Steve Ellner

222

Barbier, Jacques A.: Reform and Politics in Bourbon Chile, by Simon Collier

Berry, R. Albert, Hellman, Ronald G. and Solaun, Mauricio (eds.): Politics of Compromise: Coalition Government in Colombia, by Alan Gilbert

Betancourt, Rómulo: Venezuela; Oil and Politics, by George Philip

BRICRER, Victoria Reifler: The Indian Christ, The Indian King. The historical substrate of Maya myth and ritual, by P. G. Rivière

CARL, George E.: First Among Equals: Great Britain and Venezuela, I8I0-19ro, by D. A. G. Waddell

Carmack, Robert M.: The Quiché Mayas of Utalán: The Evolution of a Highland Guatemala Kingdom, by Warwick Bray

Cavenagr, Jonathan: Reflections on Class Theory Suggested By Analyses of the Peruvian Military Regime, 1968-79, by George Philip

Cleaves, Peter S. and Scurrah, Martin J.: Agriculture, Bureaucracy and Military Government in Peru, by George Philip

Colby, Benjamin N. and ColBy, Lore M.: The Daykeeper: The life and discourse of an Ixil diviner, by P. G. Rivière

Conniff, Michael L.: Urban Politics in Brazil: The Rise of Populism, 1925-1945, by José Murilo de Carvalo

Dibble, Charles E.: Codex en Cruz, by Warwick Bray

Dutra, Francis A.: A Guide to the History of Brazil, 1500-1822: the Literature in English, by Robert McNeil

Fitzgrrald, E. V. K.: The Political Economy of Peru 1956-68: economic development and the restructuring of capital, by George Philip

FLoRY, Thomas: Judge and Jury in Imperial Brazil, 1808-1871. Social 
Control and Political Stability in the New State, by José Murilo de Carvalho

Gardner, James A.: Legal Imperialism. American Lawyers and Foreign Aid in Latin America, by Julio Faúndez

Gellman: Irwin F.: Good Neighbor Diplomacy, by C. A. Macdonald

Golre, Jürgen: La Racionalidad de la Organización Andina, by José María Caballero

Healy, Paul F.: Archacology of the Rivas Region, Nicaragua, by Warwick Bray

Johnson, John J.: Latin America in Caricature, by Simon Collier

Jones, Grant D. and Kautz, Robert R. (eds.): The transition to statehood in the New World, by Warwick Bray

KÁDÁr, Béla: Problems of Economic Growth in Latin America, by M. H. J. Finch

Lynch, John: Argentine dictator: Juan Manuel de Rosas, 1829-1852 by Tulio Halperín Donghi

Lynch, Thomas F. (ed.): Guitarrero Cave: Early Man in the Andes, by George Bankes

Mahar, Dennis J.: Frontier Development Policy in Brazil; a Study of Amazonia, by A. R. Gross

Margolis, Maxine L. and Carter, William E. (eds.): Brazil: Anthropological perspectives. Essays in Honor of Charles Wagley, by Peter Rivière

Mathew, William M.: The House of Gibbs and the Peruvian Guano Monopoly, by Luis Ortega

Moran, Emilio F.: Developing the Amazon, by M. J. Eden

Mörner, Magnus: Historia social latinoamericana (nuevos enfoques), by John Fisher

Mörner, Magnus: Perfíl de la sociedad rural del Cuzco a fines de la colonia, by John Fisher

Moseley, Edward H. and Terry, Edward D. (eds.): Yucatán: $A$ World Apart, by Peter Coy

Moseley, Michael E. and Day, Kent C. (eds.): Chan Chan: Andean Desert City, by George Bankes

Nelson, Joan M.: Access to Power: Politics and the Urban Poor in Developing Nations, by Bryan R. Roberts

Nu'ini, Hugo G. and Bell, Betty: The Structure and Historical Development of the Compadrazgo System in Rural Tlaxcala, by Peter Coy

PAlmer, Colin A.: Human Cargoes. The British Slave Trade to Spanish America, 1700-1739, by Henry Kamen

Perkins, Whitney T.: Constraint of Empire: The United States and Caribbean Interventions, by Gordon Connell-Smith

Petras, James F. with Morley, Morris H., DeWitt, Peter and Havens, A. 
Eugene: Class, State, and Power in the Third World, with case studies on class conflict in Latin America, by David Skidmore

Reina, Ruben E. and Hill, Robert M. II: The Traditional Pottery of Guatemala, by Warwick Bray

Romero, L. A.: La Sociedad de la Igualdad. Los artesanos de Santiago de Chile y sus primeras experiencias politicas, $1820-1851$, by Simon Collier

Seligson, Mitchell A.: Peasants of Costa Rica and the Development of Agrarian Capitalism, by Michael Redclift

Sexton, James D. (ed.): Son of Tecún Umán: A Maya Indian tells his life story, by P. G. Rivière

Sмiтh, Joseph: Illusions of Conflict: Anglo-American Diplomacy Toward Latin America, 1865-1896, by Gordon Connell-Smith

Smith, Robert Freeman (ed.): The United States and the Latin American Sphere of Influence, Vol. I, Era of Caribbean Intervention: 189o1930, by Gordon Connell-Smith

Stepan, A.: The State and Society; Peru in Comparative Perspective, by George Philip

Whitaker, Irwin and Emily: A Potter's Mcxico, by Warwick Bray

Woods, Randall Bennett: The Roosevelt Foreign-Policy Establishment and the 'Good Neighbors': The United States and Argentina, by Bryce Wood

WRIGHr, Thomas C.: Landowners and Reform in Chile. The Sociedad Nacional de Agricultura, I9I9-40, by Luis Ortega

Wynia, Gary W.: The Politics of Latin American Development, by Walter Little

Zandstra, Hubert, Swanberg, Kenneth, Zulberti, Carlos and Nestel, Barry: Caqueza: Living Rural Development, by David A. Preston 


\section{NOTES FOR CONTRIBUTORS}

Journal of Latin American Studies is published twice a year under the academic sponsorship of the Centres or Institures of Latin American Studies at the Universities of Cambridge, Essex, Glasgow, Liverpool, London and Oxford.

The scope of the journal is the study of Latin America from the standpoint of the social sciences, including anthropology, archacology, economics, geography, history, international relations, politics, sociology, ete, though it is not concerned with linguistic or literary studies.

Editorial policy avoids commitment to any political viewpoint or ideology, but welcomes free discussion of such issues in the Latin American context, on the understanding that all responsibility for opinions expressed rests exclusively with the author concerned and not with either the journal or its editors.

Contriburions are invired from all parts of the world. Articles should generally not be more than 8,000 words long, and two copies, typed with double-spacing, should be subrnitved. Diagrams and maps may be included by arrangement with the editors. The journal is published in English, but articles written in other languages may be considened. and arrangements made as required for translation into English. Contributors should keep one copy of the typescript for use in correcting prooks.

All contributions and editorial correspondence should be addressed to lowrnal of Latin American Seudies. Institute of Latin American Studies, 3I Tavistock. Square, London, WCIH $9 \mathrm{HA}$.

Each contributor will receive, free of charge, 25 offprints of their article and a copy of the issue of the journal in which it appears.

\section{CONTRIBUTORS TO THIS ISSUE}

Da Linta A. Newson is Leeturer in Geography at King a Collegc, University of London.

Dr. Marcolm Dens is a Fellow of St Antony's College, Oxford.

Ma. Pal'L Gootenserag is a doctoral student in History as the University of Chicago.

Da. Julin Kiak Blackwerben is Asvistant Professor of History at the University of North Carolina, Charlottc.

Da Lrman L. Juhnson is Associate Professor of History at the University of North Carolina, Charlotte.

Dr. Lisandmo Pénez is Associate Professnr of Sociology at Louisiana State Universilty, Baton Ruuge.

Dn I. Valtale Fufer is Head of the Geography Department at Goldsmiths' College. University of London.

Da Feurpe Putocanefeo M. is Professor in the Department of Social and Historical Sciences, University of San Marcos. Lima.

Da Wat.tan l.strt.5 is Lecturer in Latin American Politics at the Universiry of Liverpool.

Dr Mats Li'Ninahl is Assuciate Professor of Economics at the University of Lund. 


\section{Journal of}

\section{Latin American Studies}

Volume if Part 2 November 1982

\section{ARTICLES}

Livda Newson: The Depopulation of Nicaragua in the

Sixteenth Century

$25.3-286$

Murcoim I) eas: The Fiscal P'roblems of Nineteenth-Century

Colombia

Pul (ioctenbers: The Social ()rigins of Protectionism in

Nineteenth-Century Lima

JtL.M KirK BLACKWELDER and LyM.IN L. JoInson: Changing

Criminal Patterns in Buenos Aires, 1890 to 1914

$287-328$

$324-35^{8}$

$359-379$

Lisandro Perez: Iron Mining and Socio-I)emographic Change

in Eastern Cuba, $188_{+}-19 f^{\circ}$

J. Vaierie Fifer: The Search for a Series of Small Successes:

Frontiers of Settlement in Fastern Bolivia

Felape. Portociarero M.: The Peruvian Public Investment

Progamme, 1968-78

Wilter Little: A Note on Political Incorporation:

The Argentine Plan Politico of 1955

$3^{81-+175}$

$f^{07-}+i^{2}$

$+33^{-}+5+$

$+55-t^{6} 3$

Mars Lendahl: Haitian Underdevelopment in a Historical

Perspective (Revieu' Article)

$f^{(1)} 5-475$

REVIEWS by

Warwick Bra!, 477-478; (icorge Bankes, $47^{8-4} 80$; P. C; Rivière, $4^{80-4} 82$; José Murilo de Carvalho, $4^{8} 3$; Lus Ortega, $4^{8} 4^{-4} 8_{7}$; Michael Redelift, $4^{87-488: ~ M . ~ J . ~ E d e n, ~} f^{88-49(): ~ D a v i d ~ S k i d m o r e, ~ f y o-f 41: ~ C i o r d o n ~}$ Connell-Smith, +91-493

SHORTER N()TICES by

Warwick Bray, +95-496: Henry Kamen, $+96-+97$; José Murilo de (arvalho, $447-498$.

(1) Cambridge University Press I082

\section{CAMBRIDGE UNIVERSITY PRESS}

The Pitt Building, Trumpington Street, Cambridge $\mathrm{CB}_{2}$ I RP

32 East $57^{\text {th }}$ Street, New York, N.Y. 10022

Prunted an Circat Britum in Neu Hestenn Pronteng Lfd. Bristol 